\title{
Essential Oils from Artemisia herba alba Asso., Maticaria Recutita L., and Dittrichia Viscosa L. (Asteraceae): A Promising Source of Eco-Friendly Agents to Control Callosobruchus maculatus Fab. Warehouse Pest
}

\author{
Allali Aimad $\mathbb{D},{ }^{1}$ Mohammed Bourhia $\mathbb{D}^{2},{ }^{2}$ Hadin Hana, ${ }^{1}$ Rezouki Sanae, \\ Ahmad Mohammad Salamatullah (D), ${ }^{3}$ Walid Soufan, ${ }^{4}$ Hail Z. Rihan $\mathbb{D}^{5,},{ }^{5,6}$ \\ Lahcen Ouahmane, ${ }^{2}$ El Abdali Youness, ${ }^{7}$ Eloutassi Noureddine, ${ }^{8}$ and Fadli Mohamed ${ }^{1}$ \\ ${ }^{1}$ Laboratory of Plant Animal and Agro-industry Productions, Faculty of Sciences, University of Ibn Tofail, Kenitra, Morocco \\ ${ }^{2}$ Laboratory of Microbial Biotechnology, Agro-sciences and Environment (BioMAgE), Cadi Ayyad University, \\ Marrakesh, Morocco \\ ${ }^{3}$ Department of Food Science \& Nutrition, College of Food and Agricultural Sciences, King Saud University, 11 P. O. Box 2460, \\ Riyadh 11451, Saudi Arabia \\ ${ }^{4}$ Plant Production Department, College of Food and Agriculture Sciences, King Saud University, P. O. Box 2460, \\ Riyadh 11451, Saudi Arabia \\ ${ }^{5}$ School of Biological Sciences, Faculty of Science and Environment, University of Plymouth, Drake Circus, PL4 8AA, \\ Plymouth, UK \\ ${ }^{6}$ Phytome Life Sciences, Launceston, PL15 7AB, UK \\ ${ }^{7}$ Laboratory of Biotechnology Environment Agri-food and Health, Faculty of Sciences Dhar El Mahraz, \\ Sidi Mohammed Ben Abdellah University, Fez, Morocco \\ ${ }^{8}$ Regional Center for the Trades of Education and Training, Fez, Morocco
}

Correspondence should be addressed to Allali Aimad; aimad.allali@uit.ac.ma and Mohammed Bourhia; bourhiamohammed@ gmail.com

Received 26 October 2021; Revised 16 December 2021; Accepted 13 January 2022; Published 30 January 2022

Academic Editor: J.B. Heredia

Copyright (C) 2022 Allali Aimad et al. This is an open access article distributed under the Creative Commons Attribution License, which permits unrestricted use, distribution, and reproduction in any medium, provided the original work is properly cited.

Callosobruchus maculatus (Fab.) (C. maculatus) is one of the major pests of legume seeds in storage causing significant damage, leading to food insecurity and low income for farmers. This work was planned to develop eco-friendly agents from essential oils of Artemisia herba alba Asso. (AEO), Maticaria Recutita L. (MEO), and Dittrichia Viscosa L. (DEO) to control C. maculatus. To achieve this goal, essential oils (EOs) were extracted by hydro-distillation using Clevenger apparatus before being characterized by GC-MS. EOs were used for testing purposes using three different tests, namely, inhalation toxicity, contact toxicity, and repellency tests. GC-MS analysis of EOs showed the presence of 16 potentially active compounds in AEO and 38 in MEO, whilst 15 compounds were identified in DEO. AEO was higher in thujone (57.6\%) and chrysanthenone (11.8\%). Santolina alcohol (40.7\%) and germacrene $\mathrm{D}(8.9 \%)$ were the major compounds identified in $\mathrm{MEO}$, whereas isocostic acid (72.3\%) was the chief compound of DEO. The obtained findings showed that the studied EOs showed considerable insecticidal activity against $C$. maculatus with a lethal dose $\left(\mathrm{LC}_{50}\right)$ of $3.78,8.86$, and $14.34 \mu \mathrm{L} / 1$ liter of air by $\mathrm{AEO}, \mathrm{MEO}$, and $\mathrm{DEO}$, respectively. At $1 \mu \mathrm{L} / 1$ liter of air, the oviposition reduction rate was $90.02 \%, 70.65 \%$, and $48.23 \%$ by AEO, MEO, and DEO, respectively, whereas the emergence reduction rate was $87.32 \%, 60.08 \%$, and $32.24 \%$ by AEO, MEO, and DEO, respectively. With increasing doses up to $20 \mu \mathrm{L} / \mathrm{L}$, the reduction of individual emergence reached $98.8 \%$ by AEO of $24 \mathrm{~h}$ after treatment. AEO, MEO, and DEO showed significant repellent effects against adults of $C$. maculatus with repulsion percentages of $60.83 \%, 50.83 \%$, and $72.5 \%$, respectively. The outcome of this work suggests that the essential oils of the studied plants, particularly Artemisia herba alba Asso. oils, can constitute a natural and environmentally friendly alternative to develop new bioinsecticides for the control of $C$. maculatus. 


\section{Introduction}

Aromatic and medicinal plants and their extracts have been traditionally used as plant-protection agents in various ancient cultures history recorded. However, chemically synthesized insecticides have gradually replaced natural insecticides during the 20th century. With the massive and sometimes irrational use of chemically synthetic insecticides generated in recent years, people are becoming increasingly aware of their harmful effects on human health and the environment besides their effectiveness in crop protection. Most of these synthetic insecticides are nondegradable and accumulate in the environment or the human body through food chains, often causing chronic diseases and other severe physiological disorders [1-5]. Although these chemicals have been more strictly regulated, it is necessary to explore new, safe, and environmentally friendly alternatives with considerable insecticidal efficacy.

Plant EOs are mixtures of bioactive, fragrant, volatile, and lipophilic secondary metabolites that are also synthesized to defend against various plant pathogens. Essential oils have been scientifically studied worldwide to control postharvest pests of cereals, legumes, citrus, tomatoes, and food-borne microorganisms [6-9].

Several studies on natural bioinsecticides have revealed that essential oils along with other secondary plant metabolites (terpenoids, polyphenols, steroids, and alkaloids) synthesized by aromatic and medicinal plants are responsible for several biological activities against plant pests, especially essential oils which have shown important insecticidal, nematicidal, acaricidal, and larvicidal properties [10-20]. Essential oils not only act as poisons or neurotropic on the nervous system of insects [21-23] but also can affect cytochrome P450, which plays a key role in the insect detoxification system, alter insect metabolism (e.g., ATP synthesis, Krebs cycle, oxidative phosphorylation, and others) [24]. Overall, the final action of EOs may be the result of more than one specific interaction with the targets, so that the possibility of insects developing resistance is greatly reduced [25].

Callosobruchus maculatus (Fab.) (Chrysomelidae), known as cowpea weevil, is one of the most well-known storage pests causing damage to chickpea (Cicer arietinum) and other leguminous crops, particularly in Africa and tropical and South American regions [26-28]. The negative economic impacts caused by this insect are related to the penetration of the larvae to feed inside the grain causing a significant loss of weight and a reduction in nutritional values and germination potential [29-32].

The Asteraceae family contains a large number of plant species, with more than 1600 genera and over 23,000 species. Some of these species, such as Matricaria recutita L., Artemisia herba alba Asso., and Dittrichia viscosa L. have already been reported to have important medicinal and nutraceutical applications. Plants belonging to the family Asteraceae can be used as insecticides thanks to the variety of bioactive molecules present in the EOs of several species.
Therefore, this study aimed to evaluate the efficacy of EOs from Artemisia herba alba Asso. and Maticaria Recutita L. and Dittrichia Viscosa L. in the control of C. maculatus because no similar has been done up to date.

\section{Materials and Methods}

2.1. Animal Material. For testing purposes, C. maculatus was isolated from a sample of chickpeas stored in the Fez. city of Fez-Morocco. Mass rearing of C. maculatus was performed in glass jars containing Cicer arietinum (chickpea) seeds. The jars were maintained at a temperature of $25 \pm 1^{\circ} \mathrm{C}$, relative humidity, and a photoperiod of 14:00 (light)/10:00 (dark) to obtain several successive generations of the insect. The nonwinged form of the adults with greater reproductive capacity was selected for testing. The active/ inactive form was determined both by the presence of flight activity, the size of the elytra, and the intensity of pigmentation on the elytra [33].

2.2. Plant Material. In this work, three medicinal and aromatic plants growing in different regions in Morocco were collected for testing purposes (Table 1).

2.3. Extraction of Essential Oils. The aerial parts of the plants were dried in the shade and ventilated area with a temperature of about $25^{\circ} \mathrm{C}$ for 5 days before distillation. The extraction of EOs from different aromatic and medicinal plants was conducted using a Clevenger apparatus [34]. Briefly, $200 \mathrm{~g}$ of each plant aerials part previously crushed was introduced into a flask with $1200 \mathrm{~mL}$ of distilled water. Next, the whole was boiled for 3 hours until complete extraction. The obtained essential oils were dehydrated on anhydrous sodium sulfate and stored at $4^{\circ} \mathrm{C}$ until further use.

The essential oil yield in percentage was calculated by the following formula:

$$
\mathrm{Y}_{\mathrm{HE}}=\frac{\mathrm{M}_{\mathrm{HE}}}{\mathrm{M}_{\mathrm{D}}} \times 100 .
$$

Here, $\mathrm{Y}_{\mathrm{HE}}$ is the yield of essential oil (\%), $\mathrm{M}_{\mathrm{HE}}$ is the mass of the $\mathrm{EO}(\mathrm{g})$, and $\mathrm{M}_{\mathrm{D}}$ is the mass of dry plant matter $(\mathrm{g})$.

2.4. Analysis of the Chemical Composition of Essential Oils. The analysis of the essential oils was performed by gas chromatography-mass spectrometry (GC-MS). The coupling was performed using an Agilent-Technologies $6890 \mathrm{~N}$ Network GC system equipped with a flame ionization detector and an HP-5MS capillary column $(30 \mathrm{~m} \times 0.25 \mathrm{~mm}$, film thickness $0.25 \mu \mathrm{m}$ ). Temperature programming from $35^{\circ} \mathrm{C}$ to $250^{\circ} \mathrm{C}$, with a gradient of $5^{\circ} \mathrm{C} / \mathrm{min}$. Retention indices were determined by gas chromatography on two fused silica capillary columns $(30 \mathrm{~m} \times 0.25 \mathrm{~mm})$ from Agilent Technologies, LittleFalls, CA, USA, with temperature programming from $35^{\circ} \mathrm{C}$ to $250^{\circ} \mathrm{C}$ at a rate of $5^{\circ} \mathrm{C} / \mathrm{min}$, with the lower and upper temperatures maintained for 3 and 10 minutes, 
TABLE 1: Plant species used for the extraction of essential oils.

\begin{tabular}{|c|c|c|c|c|c|}
\hline Species studied & Voucher specimen ID & Family & Sample site & Harvest period & Parts used \\
\hline A. herba alba & BA22/13009 & Asteraceae & Boulemane & June 2019 & Leaves \\
\hline M. recutita & BM19/09549 & Asteraceae & Taounate & April 2019 & Leaves \\
\hline D. viscosa & BD01/00282 & Asteraceae & $\mathrm{Fez}$ & August 2019 & Leaves \\
\hline
\end{tabular}

respectively. The carrier gas (helium) flow rate was $1.0 \mathrm{~mL} /$ min. A $1.0 \mu \mathrm{L}$ sample was injected in splitless mode. The essential oil constituents were identified by comparing their mass spectra with those of the NIST02GC/MS library data and the Adams.

\subsection{Toxicity of Essential Oils}

2.5.1. Contact Toxicity. To evaluate the effect of each EO, $100 \mathrm{~g}$ of seed infested by five pairs of insects (male and female) aged 0 to $48 \mathrm{~h}$ were used. The tests were packaged in glass containers $(1 \mathrm{~L})$ duly closed with a perforated lid and covered with a thin transparent cloth. The essential oils were added directly to the seeds with a pipette, followed by manual shaking for 2 minutes. After $48 \mathrm{~h}$ of confinement, adult mortality was assessed [35]. A control for each test was performed under the same conditions without the EOs. Based on the results obtained in the preliminary tests, treatments with increasing concentrations $(1,5,10,20 \mu \mathrm{L} /$ 1 liter of air) were performed. After 24 hours, mortality was assessed, and dead insects were removed. Eggs deposited in the grains were also counted after 12 days from the start of the tests, followed by a regular count of emerged insects from Day 28 after confinement.

The observed mortality rate was corrected by the Abbott formula as follows:

$$
\mathbf{P c}=100 \times \frac{\mathbf{P} 0-\mathbf{P t}}{100-\mathbf{P t}} .
$$

Here, $\mathbf{P c}$ is the corrected mortality percentage (\%), Po is the mortality observed in the test, and $\mathbf{P t}$ is the mortality observed in the control.

The reduction percentage in the number of eggs and adults emerging in each concentration of essential oil was calculated using the following formula:

$$
\mathbf{P R}=\frac{\mathbf{N C}-\mathbf{N T}}{\mathbf{N C}} \times 100 .
$$

Here, PR is the percentage of oviposition (\%), NC is the number of eggs laid in the control, and NT is the number of eggs in the experiment.

2.5.2. Inhalation Toxicity. In $1 \mathrm{~L}$ glass jars with tightly closed lids, each containing $10 \mathrm{C}$. maculatus bruchids (male and female) ranging in age from 0 to $48 \mathrm{~h}$, small cotton balls were suspended with a thread attached to the inside of each lid. Using a micropipette, doses of $1 \mu \mathrm{L}, 5 \mu \mathrm{L}, 10 \mu \mathrm{L}$, and $20 \mu \mathrm{L} / \mathrm{L}$ of each essential oil were each deposited into the above cotton balls. For each dose, three replicates were performed. The comparison was made to a control sample (cotton without essential oil) [36].
The observed mortality rate is corrected by the Abbott formula and calculated as follows:

$$
\mathbf{P c}=100 \times \frac{\mathbf{P} 0-\mathbf{P t}}{100-\mathbf{P t}} .
$$

Here, $\mathrm{Pc}$ is the corrected mortality percentage (\%), Po is the mortality observed in the test, and Pt is the mortality observed in the control.

2.6. Repulsion Test. The repellent effect of the studied essential oils on C. maculatus adults was evaluated using the preferential area method on filter paper described by McDonald et al. [37]. Briefly, $9 \mathrm{~cm}$ diameter filter paper discs used for this purpose were divided into two halves with $31.80 \mathrm{~cm}^{2}$ area in each. Next, $0.5 \mathrm{~mL}$ of each EOs solutions previously prepared in acetone $(1,5,10$, and $20 \mu \mathrm{L} / \mathrm{mL}$ of acetone) was uniformly spread on one of the two disc halves in order to obtain doses such as $0.016,0.079,0.157$, and $0.315 \mu \mathrm{L} / \mathrm{cm}^{2}$ per disc. While the other half received only $0.5 \mathrm{~mL}$ of acetone. The Petri dishes were then sealed with Parafilm. After 30 minutes, the number of bruchids presents on the half of the disc treated with the essential oil was counted against the number on the untreated part. Three replicates for each experiment were done under the same environmental conditions as the insect breeding.

The percentage of repulsion (PR) was calculated according to the following formula [38]:

$$
\mathbf{P R}=\frac{\mathbf{N C}-\mathbf{N T}}{\mathbf{N C}+\mathbf{N T}} \times 100 .
$$

Here, $\mathbf{P R}$ is the percentage of repulsion (\%), NC is the number of insects in the control area, and NT is the number of insects in the treated area.

The average percentage of repulsion was calculated for each EO assigned to one of the different repulsive classes ranging from $0 \%$ to $100 \%$ [39].

2.7. Data Analysis. SPSS for Windows ${ }^{\circledR}$ (version 21.0) statistical software was used to perform analysis. Data were treated with a one-way analysis of variance (ANOVA) to determine the difference between the extreme values of the group. Fisher's minimum significant difference (LSD) test was used to separate significant from nonsignificant means at $\alpha=0.05$. Lethal concentrations $\mathrm{LC}_{50}$ and $\mathrm{LC}_{95}$ with their confidence intervals were determined using the probit method [40].

\section{Results}

3.1. Essential Oil Yield. The extracted EOs were found to be different in terms of specific characteristics, especially in odor and color. The values of the essential oil yields varied 
from one species to another with highly significant differences $(F=1179.71 ; P<0.001)$. From Figure 1 , it can be seen that the highest yield of EOs was recorded for A. herba alba with a value of $1.18 \pm 0.15 \%$, followed by $M$. recutita $(0.45 \pm 012 \%)$ and $D$. viscose $(0.23 \pm 0.06 \%)$.

3.2. Chemical Composition of Essential Oils. The compounds identified in the EOs of the three studied plants along with their retention index and percentages are figured in Figures 2-4 and Table 2, whereas the chemical formulas of the chief compounds are presented in Table 3. The obtained results revealed the presence of 16 potentially bioactive compounds in AEO and 38 in MEO, whilst 15 compounds were identified in DEO. The main compounds identified in AEO were thujone (57.6\%) and chrysanthenone (11.8\%). Santolina alcohol (40.7\%) and germacrene D (8.9\%) were the major compounds identified in MEO, whereas, isocostic acid (72.3\%) was the chief compound of DEO.

3.3. Inhalation Toxicity of Essential Oils. In this test, EOs at different doses $(0,1,5,10$, and $20 \mu \mathrm{L} / 1$ litre air) were used to evaluate their toxicity against $C$. maculatus through inhalation. Adult mortality was recorded every 24 hours for 4 days. The obtained results are illustrated in Figures 5-7.

According to the results obtained, most of the essential oils studied showed a considerable insecticidal effect with a significant difference $(P<0.001)$ in the longevity of the treated adults depending on the dose and duration of exposure. The mortality of C. maculatus adults increased with increasing doses and duration of exposure to essential oils. A reduction in mortality was observed in chickpea bruchid adults treated with the lowest dose $(1 \mu \mathrm{L})$ of $A$. herba alba essential oils causing total mortality after $96 \mathrm{~h}$ of exposure, thus reflecting their powerful insecticidal effect. At higher doses, and after $96 \mathrm{~h}$ of exposure, all three essential oils show a total insecticidal effect at the $20 \mu \mathrm{L}$ dose.

The probit method (Table 4) allows calculating the lethal concentrations (LC50) which cause the mortality of $50 \%$ of the adults of $C$. maculatus treated with essential oils. The results obtained (Table 3 ) allow us to classify the tested EO from the most toxic to the least toxic according to the following order: A. herba alba, $M$. recutita, and $D$. viscosa whose LC50 are, respectively, 2.18, 4.09, and $19.96 \mu \mathrm{L} / 1$ litre of air volume.

3.4. Contact Toxicity of Essential Oils. The action of essential oils of different aromatic plants by direct contact on the biology of the C. maculatus insect was also studied. In this regard, the tests performed concerned the longevity of the adults, the fecundity of the females, and the viability of the eggs. In view of the results illustrated in Figures 8 to 10, all the essential oils tested showed a more or less significant insecticidal effect depending on the dose and duration of exposure.

In general, mortality of $C$. maculatus adults increased significantly $\left(P^{<} 0.001\right)$ with increasing EO doses, or when contact time with the oil was extended to nearly $96 \mathrm{~h}$. EOA

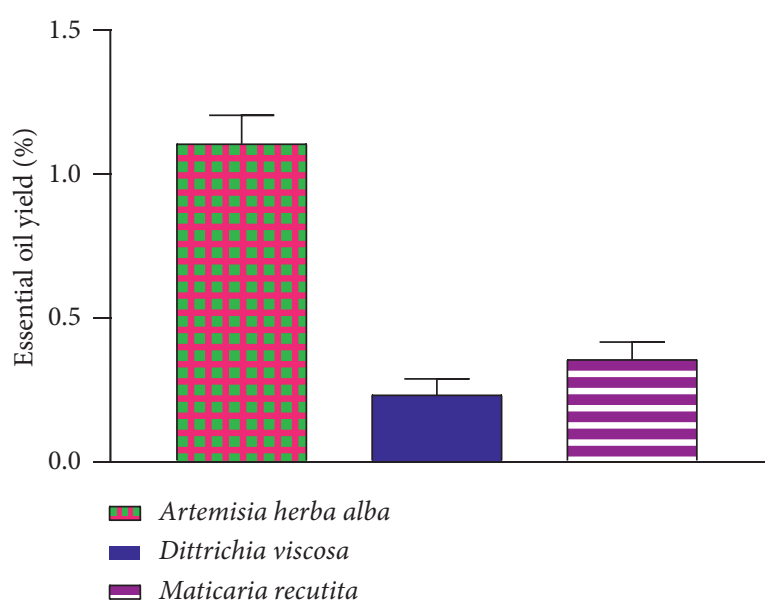

Figure 1: Essential oil yield of the studied plants.

was found to be the most toxic against $C$. maculatus with total mortality $(100 \%)$ recorded for a dose of $(5 \mu \mathrm{L}) 4$ days postcontact. In the case of EOM and EOD, total mortality $(100 \%)$ was achieved by increasing the doses up to $10 \mu \mathrm{L}$.

Based on the results of the contact test with EOs at different doses, the lethal concentrations $\mathrm{LC}_{50}$ and $\mathrm{LC}_{95}$ causing mortality of $50 \%$ and $95 \%$ of C. maculatus adults respectively were calculated according to the Probit method (Table 5), and the obtained values are shown in Table 4. This allowed us to classify the EOs tested by contact according to their degree of toxicity from the most toxic to the least toxic using the following classification: EMA, EOM, and EOD whose LC50 are respectively $3.78,8.86$, and $14.17 \mu \mathrm{L} / 1$ litre of air.

3.5. Effect of Direct Contact with Essential Oils on Fecundity and Emergence of Callosobruchus maculatus Fab. Individuals. Fecundity in C. maculatus occurred within $24 \mathrm{~h}$ after mating. In this contact test, the fecundity process was evaluated in the presence of EOs of different aromatic plants. The obtained results are displayed in Figure 11. From this figure, it can be seen that the number of eggs laid varies according to the EOs and the doses used. Thus, the average fecundity in the control batches was $184.67 \pm 17.78$ eggs/five females. This process decreased significantly $\left(P^{<} 0.001\right)$ with increasing doses of EOs. Indeed, at the highest dose $(20 \mu \mathrm{L}), \mathrm{EOA}$, EOD, and EOM significantly affect the fertility of C. maculatus, which was reduced to $6 \pm 2,19.33 \pm 7.50$, and $57.66 \pm 12.58$ eggs/female, so that the percentage of reduction was of $96.79 \%, 89.69 \%$, and $68.95 \%$, respectively (Figure 12).

After the emerged individuals of C. maculatus completed their developmental cycle, they were subjected to evaluation of emergence under different doses of EOs and the obtained results of the test are presented in Figures 13 and 14. In this regard, EOs significantly reduced number of $C$. maculatus emergences when compared to the control batches $(111.67 \pm 4.44)(P<0.001)$. Moreover, at $20 \mu \mathrm{L} / 1$ litre of air, only $1.33 \pm 0.57,9.67 \pm 2.31$, and $21.67 \pm 2.03$ individuals emerged in the presence of EOA, EOM, and EAD respectively. 


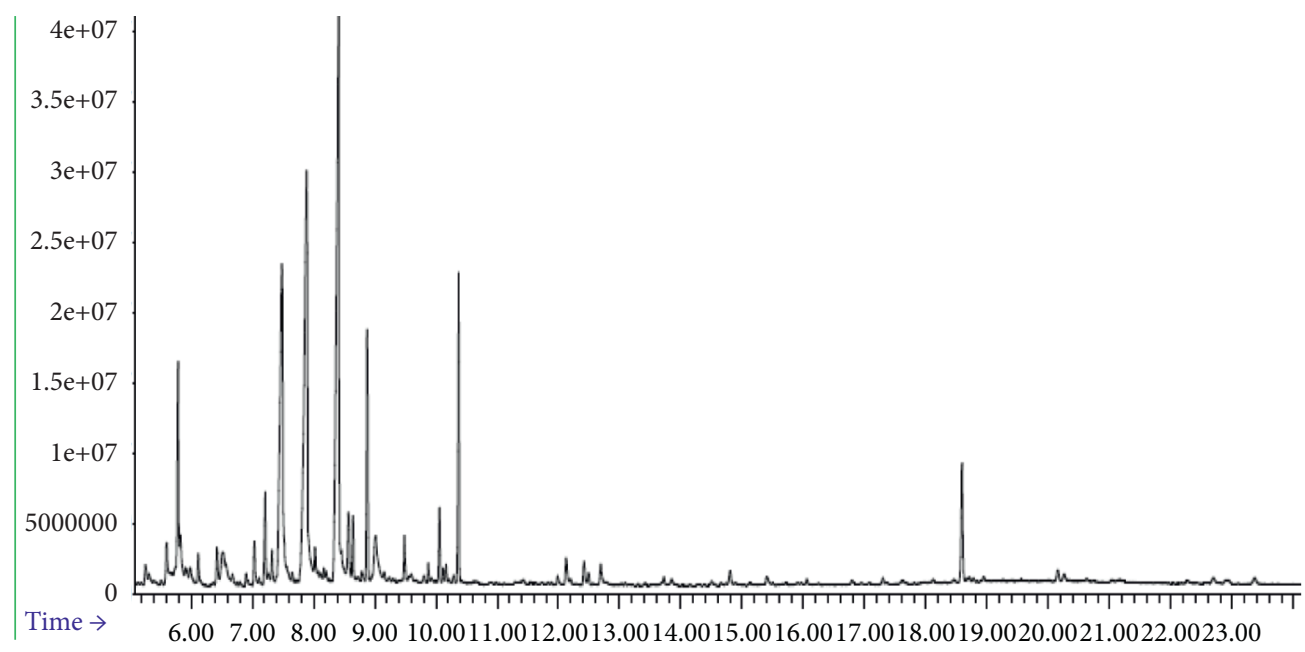

Figure 2: Chromatogram of Artemisia herba alba Asso.essential oil.

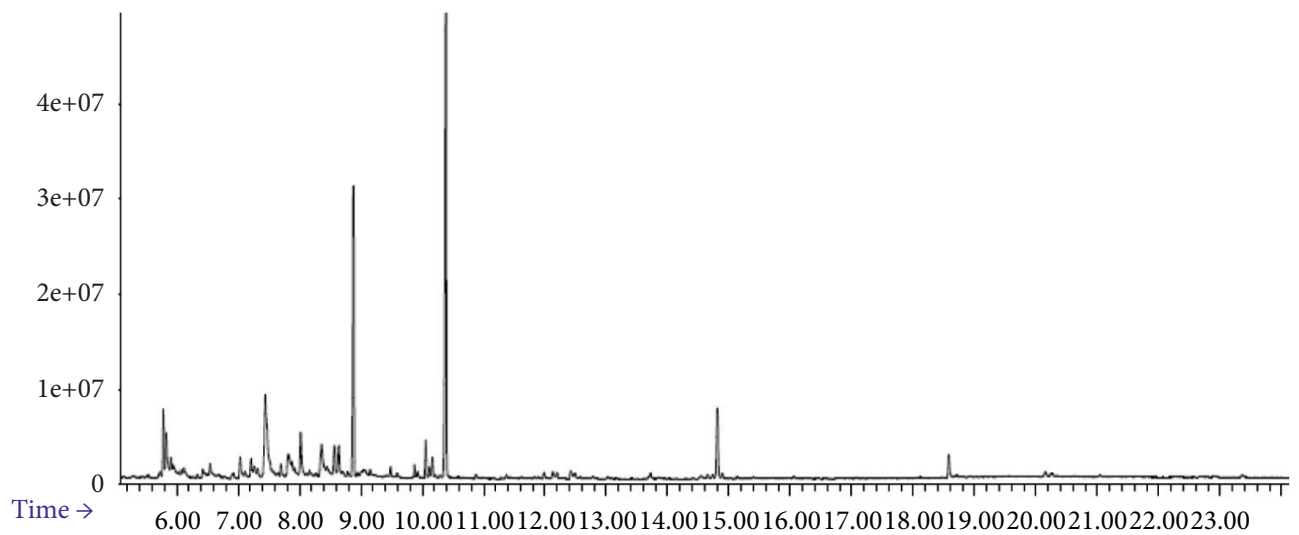

Figure 3: Chromatogram of Matricaria recutita L. essential oil.

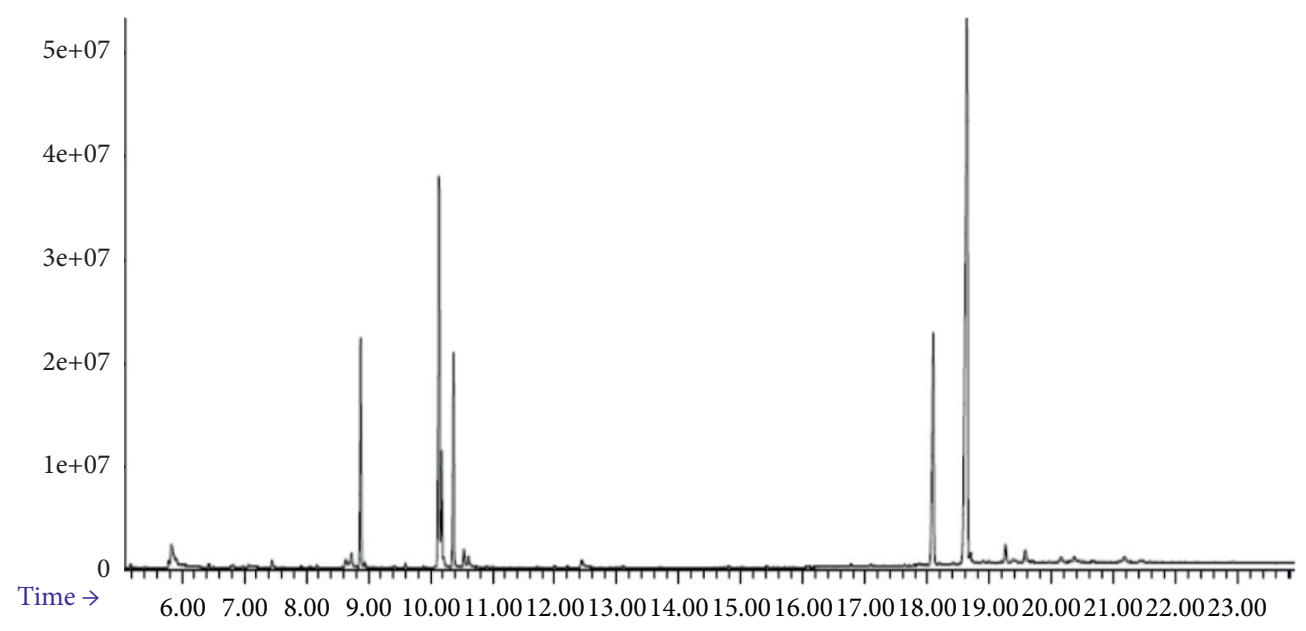

Figure 4: Chromatogram of Dittrichia viscosa L. essential oil.

3.6. Repulsive Activity of Essential Oils. The results of the repulsion test are given in Figure 15. Overall, the EOs were found to be repulsive to adults of C. maculatus. The obtained results showed that the repulsive activity of the studied EOs was in a dose-dependent manner. From Table 5, it can be seen that with increasing concentration up to $20 \mu \mathrm{L}$, the mean of repulsive activity by EOD reached $72.5 \%$. Regarding the repulsive activity, the analysis of variance showed significant differences $\left(P^{<} 0.001\right)$ in EOM and EOD towards C. maculates (Figure 15). 
TAвle 2: Chemical composition of essential oils from Artemisia herba alba Asso., Matricaria recutita L., and Dittrichia viscosa L.

\begin{tabular}{|c|c|c|c|c|}
\hline \multirow{2}{*}{ Compounds } & \multirow{2}{*}{$\mathrm{RI}$} & \multicolumn{3}{|c|}{ Relative percentage } \\
\hline & & A. herba alba & M. recutita & D. viscosa \\
\hline$\alpha$-Pinene & 937 & 0.6 & 5.7 & - \\
\hline Camphene & 954 & 2.3 & 0.2 & - \\
\hline Sabinene & 972 & 0.7 & 0.1 & - \\
\hline b-Pinene & 974 & - & 0.3 & - \\
\hline Myrcene & 992 & - & 0.5 & - \\
\hline Yomogi alcohol & 986 & - & 3.0 & - \\
\hline p-Cymene & 1025 & 0.2 & 0.1 & - \\
\hline Limonene & 1028 & - & 3.1 & - \\
\hline 1,8-Cineole & 1030 & 11.7 & 0.3 & - \\
\hline Santolina alcohol & 1037 & - & 40.7 & - \\
\hline g-Terpinene & 1072 & 0.3 & - & - \\
\hline Artemesia alcohol & 1080 & - & 4.3 & - \\
\hline a-Thujone & 1109 & 29 & - & - \\
\hline b-Thujone & 1112 & 28.6 & - & - \\
\hline Campholenal & 1121 & - & 0.1 & - \\
\hline (E)-Pinocarveol & 1139 & - & 1.3 & - \\
\hline Camphor & 1146 & 0.2 & - & - \\
\hline Chrysanthenone & 1158 & 14.8 & - & - \\
\hline Borneol & 1164 & 0.1 & 0.3 & - \\
\hline Pinocarvone & 1166 & - & 1.9 & - \\
\hline Santolinaacetate & - & - & 2.2 & - \\
\hline Terpinen-4-ol & 1173 & - & 0.3 & - \\
\hline trans-Pinocarveol & 1178 & 1.9 & - & - \\
\hline a-Terpineol & 1199 & - & 0.2 & 0.1 \\
\hline Hexylisovalerate & - & - & 0.1 & - \\
\hline Acetate de bornyl & 1289 & 0.1 & 1.0 & - \\
\hline Phenethylacetate & - & - & 0.1 & - \\
\hline trans-Sabinylacetate & 1299 & 0.3 & - & - \\
\hline$\alpha$-Copaene & 1377 & - & 0.1 & - \\
\hline b-Bourbonene & 1380 & 0.2 & - & - \\
\hline$\beta$-Maaliene & $*$ & - & 0.4 & - \\
\hline$\beta$-Elemene & 1392 & - & 0.6 & - \\
\hline B-Caryophyllène & 1419 & - & 1.7 & 1.8 \\
\hline (E)- $\beta$-Farnesene & 1456 & - & 4.0 & - \\
\hline$\gamma$-Curcumene & 1479 & - & - & 0.3 \\
\hline$\alpha$-Humulene & 1480 & - & 0.4 & - \\
\hline Germacrene D & 1492 & 4.3 & 8.9 & - \\
\hline$\delta$-Selinene & 1493 & - & - & 0.2 \\
\hline$\alpha$-Muurolene & 1503 & - & 1.0 & 0.7 \\
\hline$\delta$-Cadinene & 1520 & - & 1.1 & - \\
\hline trans- $\gamma$-Cadinene & 1513 & - & - & 0.1 \\
\hline (Z)-Nerolidol & 1536 & - & 0.3 & - \\
\hline Germacrene D-4-ol & 1570 & - & 1.6 & - \\
\hline Caryophylleneoxide & 1579 & - & 0.9 & - \\
\hline Caryophylladienol & - & - & 2.8 & - \\
\hline 10-Epi- $\gamma$-eudesmol & 1623 & - & - & 3.4 \\
\hline Caryophylla-4(14),8(15)-dien-5-ol & 1636 & - & - & 0.6 \\
\hline Epi-a-cadinol & 1639 & & 1.2 & - \\
\hline Epi- $\alpha$-muurolol & 1640 & - & 1.6 & - \\
\hline$\alpha$-muurolol & 1641 & - & 0.6 & - \\
\hline a-Cadinol & 1643 & - & 1.4 & - \\
\hline Cedr-8(15)-en- 9 - $\alpha$-ol & 1650 & - & - & 0.4 \\
\hline Selin-11-en-4- $\alpha$-ol (=Kongol) & 1653 & - & - & 2.5 \\
\hline Ylangenal & 1675 & - & - & 2.4 \\
\hline Junipercamphor & 1692 & - & - & 5.1 \\
\hline Isocosticacid & 1890 & - & - & 72.3 \\
\hline Phytolacetate & 2223 & - & - & 0.9 \\
\hline Monoterpenes & & 90.4 & 62.5 & 0.1 \\
\hline Sesquiterpenes & & 4.5 & 30.8 & 89.8 \\
\hline
\end{tabular}


TABLE 2: Continued.

\begin{tabular}{lcccc}
\hline \multirow{2}{*}{ Compounds } & \multirow{2}{*}{ Relative percentage } \\
& & A. herba alba & M. recutita & D. viscosa \\
\hline & Others & $\mathbf{0 . 4}$ & $\mathbf{3 . 3}$ & $\mathbf{0 . 9}$ \\
& Total identified & $\mathbf{9 5 . 3 \%}$ & $\mathbf{9 6 . 6 \%}$ & $\mathbf{9 0 . 8 \%}$ \\
\hline
\end{tabular}

TABle 3: Major compounds of essential oils of Artemisia herba alba Asso., Matricaria recutita L., and Dittrichia viscosa L.

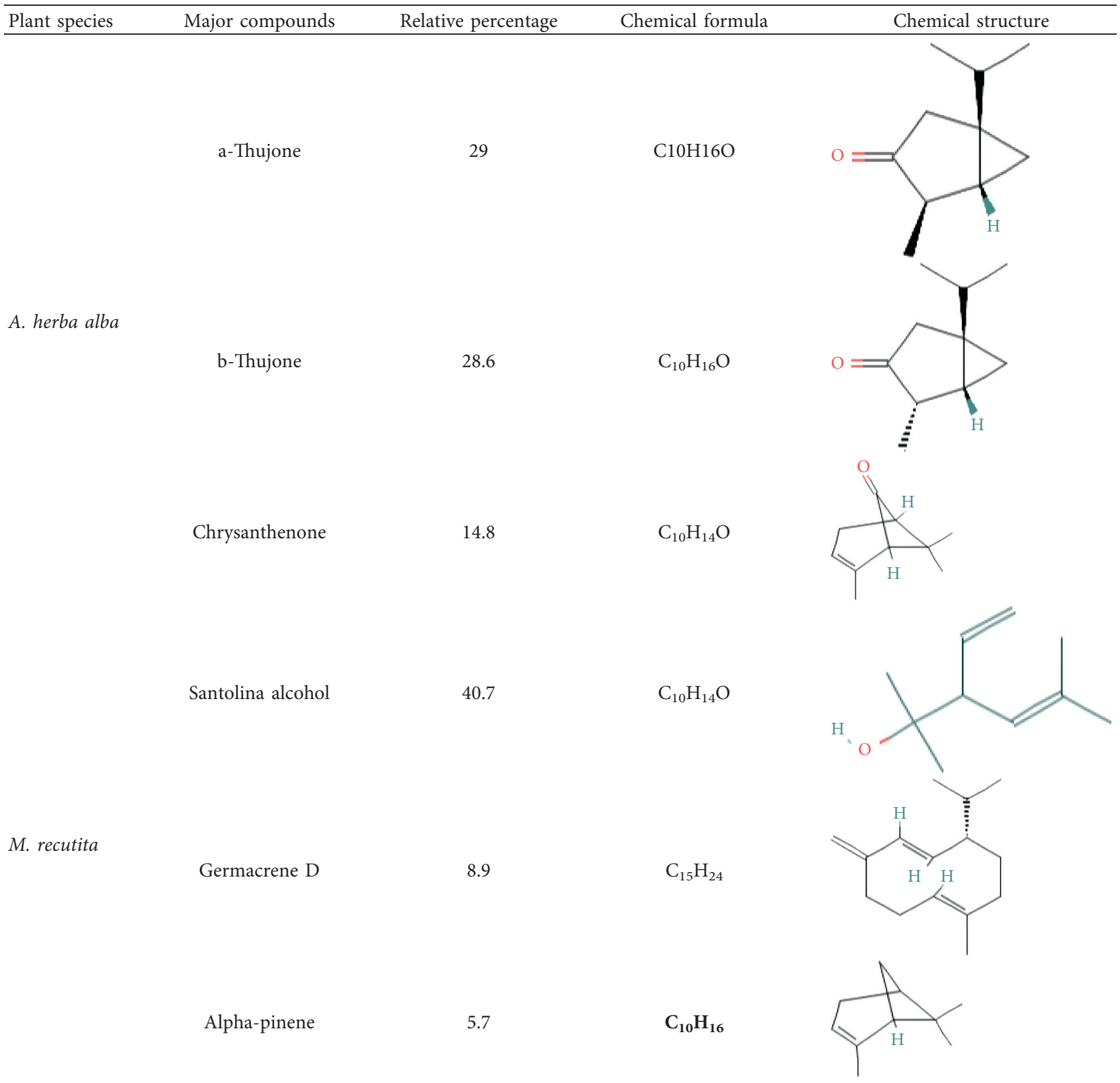


TABle 3: Continued.

\begin{tabular}{llll}
\hline Plant species & Major compounds & Relative percentage \\
\hline Isocostic acid & Chemical formula \\
D. Viscosa & $\begin{array}{c}\text { Juniper camphor } \\
\text { 10-Epi- } \gamma \text {-eudesmol }\end{array}$
\end{tabular}

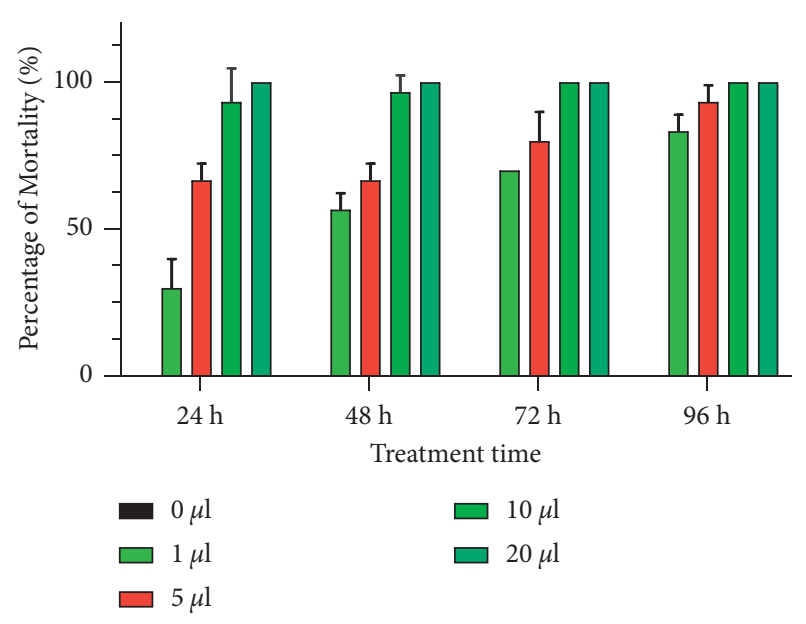

FIGURE 5: Mortality rate of Callosobruchus maculatus Fab. adults exposed to the inhalation test of Artemisia herba alba L. essential oils.

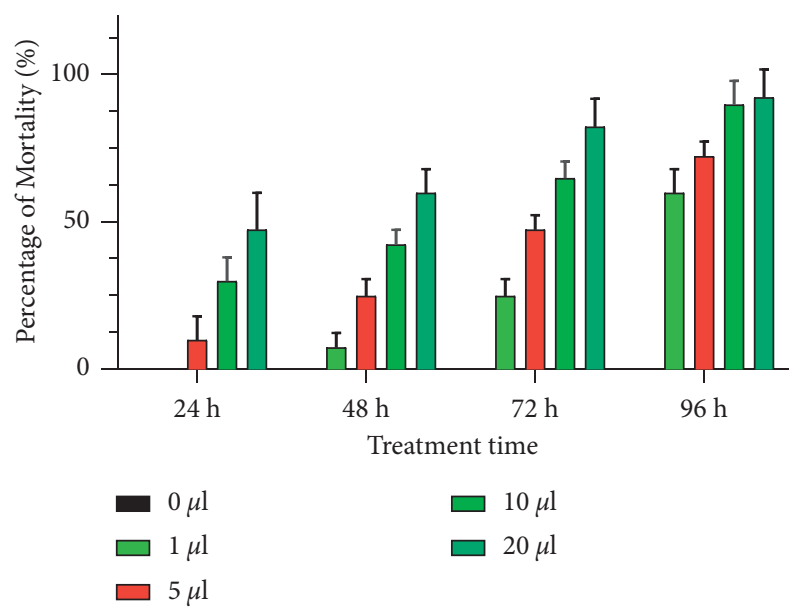

FIgURE 6: Mortality rate of Callosobruchus maculatus Fab. adults exposed to the inhalation test of Dittrichia viscosa L. essential oils.

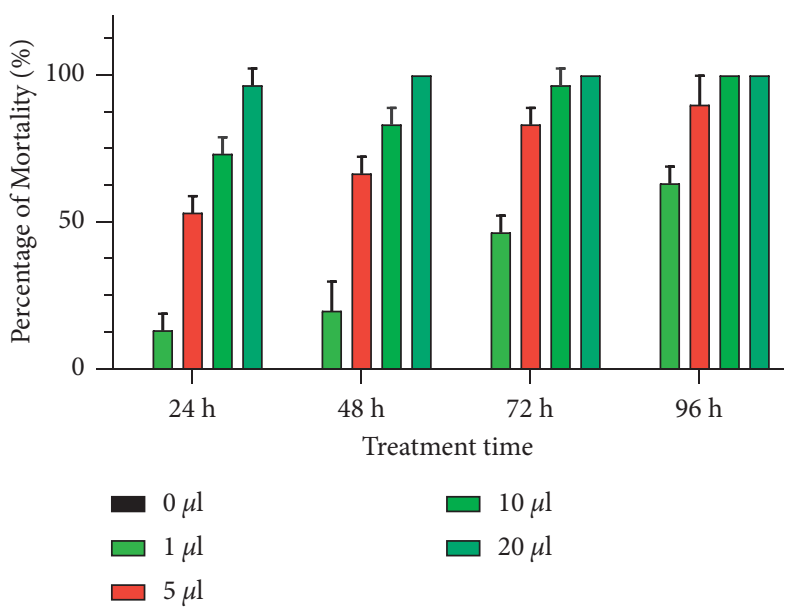

FIgURE 7: Mortality rate of Callosobruchus maculatus Fab. adults exposed to the contact test of Matricaria recutita essential oils.

The percentage of repellency calculated by the method of McDonald et al. [37] showed that the EOA and EOD were repulsive with respective rates of $60.83 \%$ and $72.5 \%$, whereas, EAM was moderately repulsive (50.83\%).

\section{Discussion}

This study aimed to investigate the chemical composition and insecticidal activity of EOs from A. herba alba, M. Recutita., and D. Viscosa on C. maculatus. The obtained results in this context showed that EOs yields in these plants ranged from $0.23 \pm 0.06 \%$ to $1.18 \pm 0.15 \%$. It is thus fitting that these yields were relatively low when compared to some industrially exploited plants as sources of essential oils [41]. Many factors influence the yield, content, physicochemical characteristics, and chemical composition of essential oils such as plant species, environmental conditions, extraction technique, drying, harvesting time and environment, cultivation practices, and age of plant material [39]. 
TABLE 4: LC50 and LC95 values ( $\mu \mathrm{L} / 1$ litre of air) calculated based on the mortality of $C$. maculatus adults after 24 h exposure to various concentrations of essential oils in the inhalation test.

\begin{tabular}{lcccc}
\hline Treatment & DF & Slope + ES & LC $_{50}($ IC 95\%) & LC $_{95}($ IC 95\%) \\
\hline A. herba alba & 2 & $1.91 \pm 0.17$ & $2.18(0.12 ; 5.26)$ & $15.82(6.22 ; 7720.86)$ \\
M. recutita & 2 & $2.02 \pm 0.18$ & $4.09(1.42 ; 7.99)$ & $26.73(11.99 ; 519.77)$ \\
D. viscosa & 2 & $2.09 \pm 0.3$ & $19.96(16.27 ; 27.09)$ & $14.66(12.95 ; 17.43)$ \\
\hline
\end{tabular}

C50 and LC90 were the concentration of causing 50\% and 90\% mortality against larvae after $24 \mathrm{~h}$; slope: measures of inclination of the line probit $(p)=$ constant $+B x$ (covariates $x$ transformed using log base 10; $\mathrm{SE}=$ standard error; $95 \%$ CI: 95\% confidence interval; $\chi^{2}=$ chi-square.

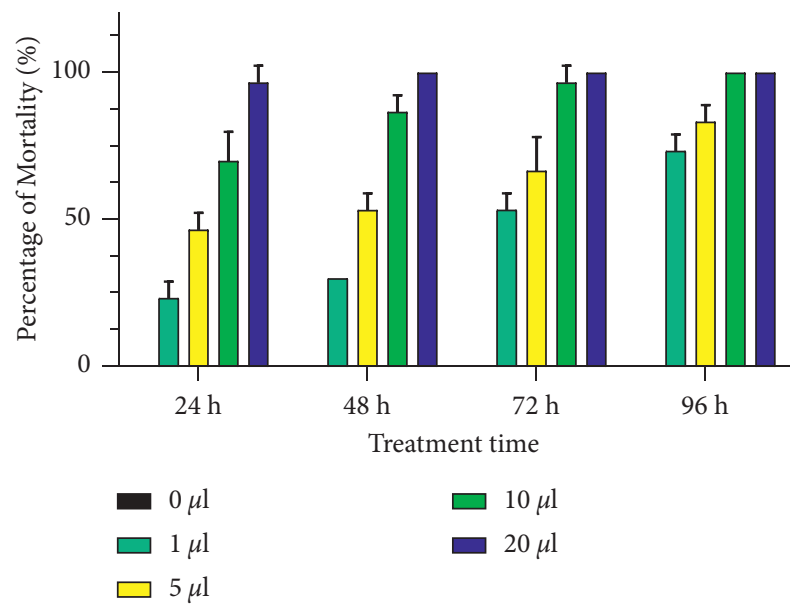

FIGURE 8: Mortality rate of Callosobruchus maculatus Fab. adults exposed to the contact test of Artemisia herba alba L. essential oils.

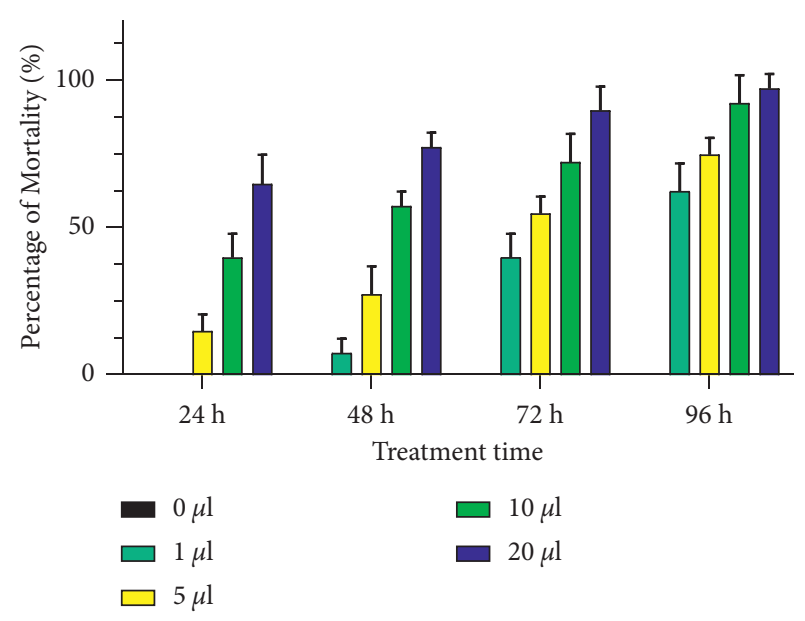

FIgURE 9: Mortality rate of Callosobruchus maculatus Fab. adults exposed to a contact test of Dittrichia viscosa L. essential oils.

The chemical composition of EOs investigated here was similar to that described in previous investigations. Our findings revealed that AEO was higher in thujone (57.6\%) and chrysanthenone $(11.8 \%)$, whilst MEO was higher in santolina alcohol (40.7\%) and germacrene D (8.9\%). Isocostic acid (72.3\%) was the chief compound of DEO so that these results were consistent with prior works [41-43].

This study evaluated the insecticidal activity of EOs by inhalation on adult individuals of C. maculatus using multiple doses and exposure times. The obtained results indicated that inhalation treatments with EOs from the studied aromatic plants considerably affect the longevity of

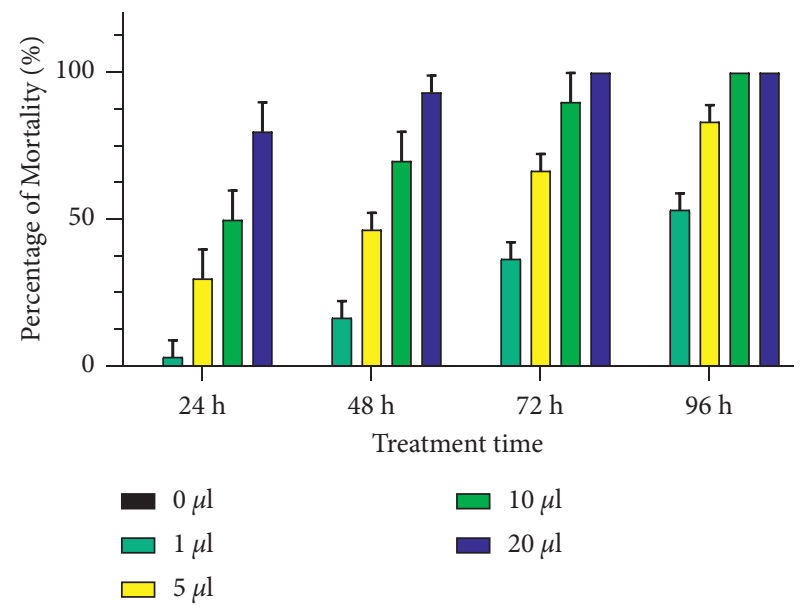

Figure 10: Mortality rate of Callosobruchus maculatus Fab. adults exposed to a contact test of Matricaria recutita L. essential oils.

C. maculatus adults. Overall, the mortality averages of C. maculatus adults became increasingly important with increasing dose and duration of exposure to EOs. Our results were in harmony with those obtained by many authors $[36,44-46]$, who reported the insecticidal effect of EOs of many aromatic plants. The studied EOs here provide new perspectives in the control of C. maculatus. For comparison purposes, Mahmoudvand et al. [47]observed that EOs of Lippia citrodora L., Rosmarinus officinalis L., Mentha piperita L., and Juniperus Sabina L. caused mortality of genus Callosobruchus. Aboua et al. [48] showed that EOs of Melaleuca quinquenervia L., Citrusaurantifolia (Christm.), and Ageratum conyzoides L. possessed fumigation toxicity effects against this pest. Carum copticumand Vitex pseudonegundo oils also posed effects on the genus Callosobruchus at different stages of insect development [49].

In this work, three EOs extracted from Moroccan aromatic plants were tested by direct contact at different doses in order to evaluate their insecticidal effects on C. maculatus adults along with their reproduction (fecundity and emergence). In this instance, the results showed that the EOs of the studied aromatic plants had well-controlled the longevity of the insect and clearly limited its fecundity and emergence in a dose- and time-dependent manner. In this sense, the EOA was the most effective, whereas, EOM was the least effective in terms of toxicity against C. maculatus.

Numerous studies have demonstrated the action of EOs on the longevity of adults of different species of stored grain pests. Due to their high volatility, EOs and their constituents, particularly monoterpenes, exert insecticidal effects, and reduce or disturb the insect growth at different stages of their 
TABLE 5: LC50 and LC95 values ( $\mu \mathrm{L} / 1$ litre of air) calculated for mortality of C. maculatus adults after $24 \mathrm{~h}$ of postcontact with various concentrations of essential oils.

\begin{tabular}{|c|c|c|c|c|c|}
\hline Treatment & $\mathrm{DF}$ & Slope + ES & $\mathrm{LC}_{50}(\mathrm{IC} 95 \%)$ & $\mathrm{LC}_{95}(\mathrm{IC} 95 \%)$ & $x^{2}$ \\
\hline A. herba alba & 2 & $1.62+0.15$ & $3.78^{*}$ & $39.24^{*}$ & 16.15 \\
\hline$M$. recutita & 2 & $2.06+0.21$ & $8.86(7.55,10.48)$ & $55.62(39.22,92.19)$ & 1.63 \\
\hline D. viscosa & 2 & $2.47+0.30$ & $14.17(12.24,16.99)$ & $65.31(44.98,193.93)$ & 0.35 \\
\hline
\end{tabular}

C50 and LC90 were the concentration causing 50\% and 90\% mortality against larvae after $24 \mathrm{~h}$ of posttreatment; slope: measures of inclination of the line probit $(p)=$ constant $+B x$ (covariates $x$ transformed using using log based 10; SE $=$ standard error; $95 \%$ CI: 95\% confidence interval; $\chi^{2}=$ chi-square. ${ }^{*}$ Wide confidence intervals were excluded from the calculation.

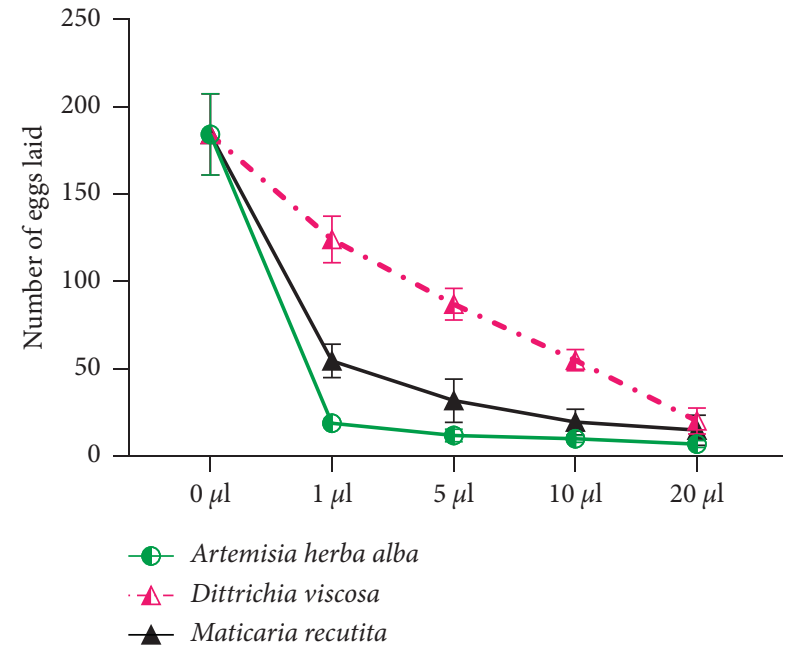

FIgURE 11: Effects of essential oils on the number of eggs laid by females of Callosobruchus maculatus Fab.

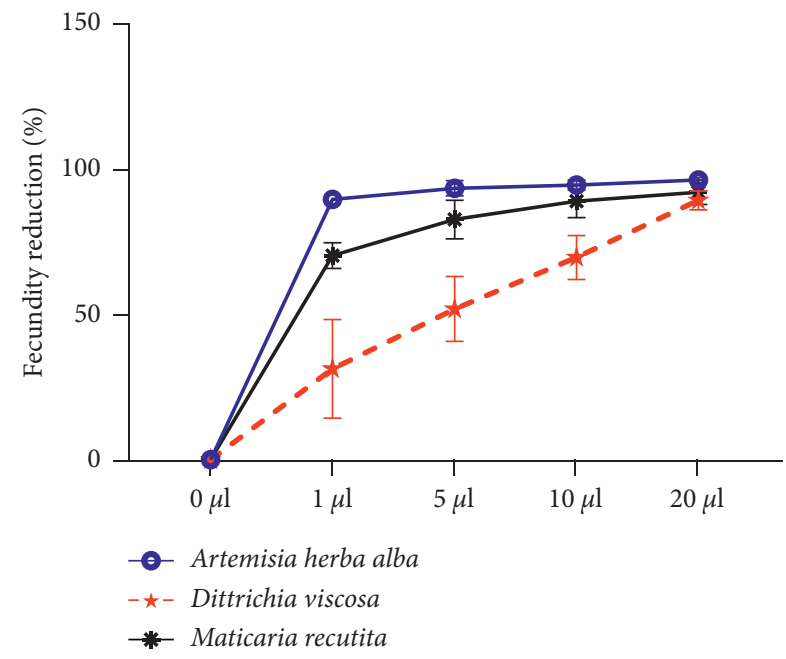

FIGURE 12: Rate of the fertility reduction in females under the effect of EOs.

life $[45,50-53]$. It was reported that EOs' efficiencies are closely related to the phytochemical profile and the entomological target [54].

A. herba alba Asso. is among the most important species of the family Asteraceae, which has been the subject of various chemical and biological studies, including insecticidal properties $[55,56]$. It is thus fitting that our results are in agreement with those reported by Hussain [57], who

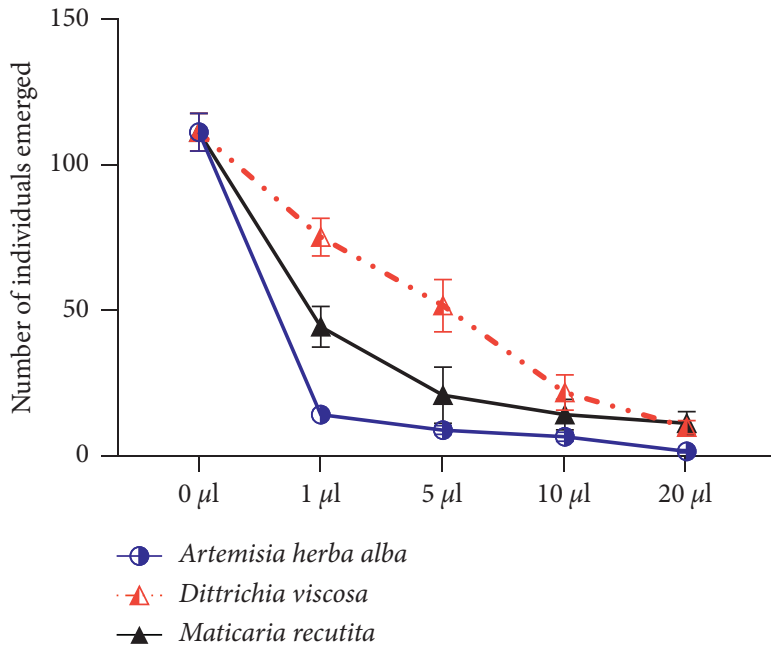

FIGURE 13: Effects of essential oils on the number of individuals emerging after the completion of life cycle.

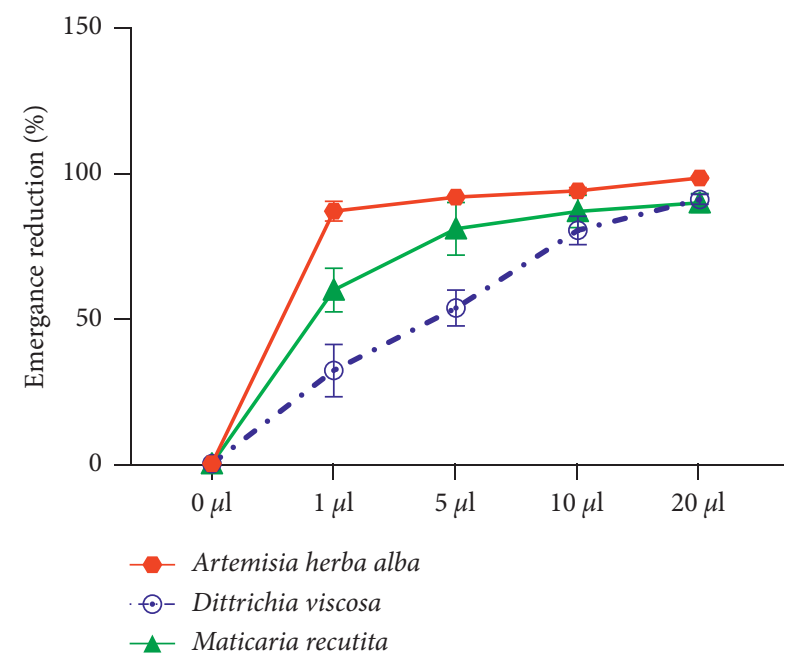

FIGURE 14: Rate of the reduction of Callosobruchus maculatus Fab. emergence under the effect of essential oils.

investigated the insecticidal properties of A. herba alba Asso on other insects. In addition, Abdelgaleil et al. [58] and Aggarwal et al. [59] reported that the insecticidal properties of many Artemisia species are due to the presence of 1,8cineole. Furthermore, Bachrouch et al. [60] reported that the high percentages of $\alpha$ Thujone, 1,8-cineole, and norboran-2one in the essential oil of $A$. herba alba conferred it the best insecticidal potential against two stored commodity insects 


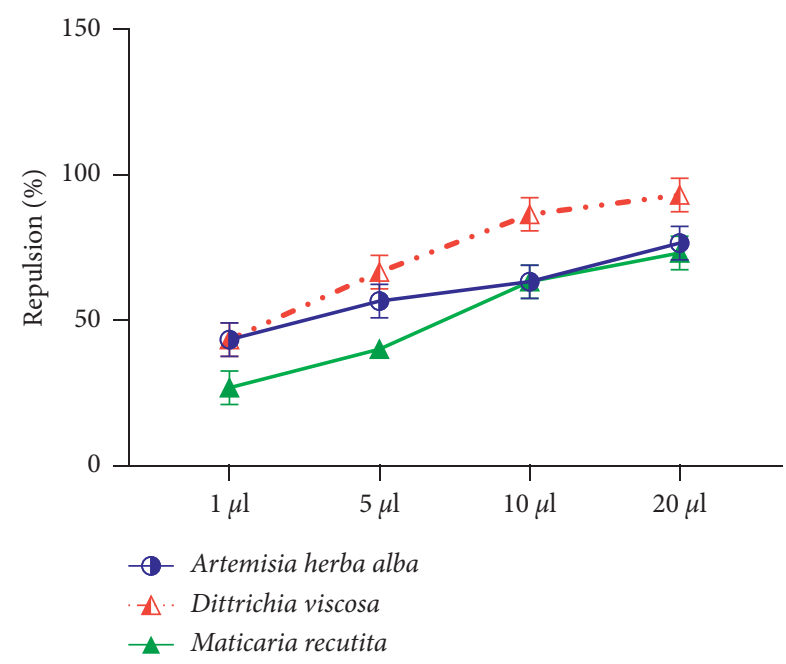

FIGURE 15: Repulsive effects of essential oils against Callosobruchus maculatus Fab.

including Oryzaephilus surinamensis (L.) and Tribolium castaneum (Herbst). Therefore, we can confirm that the insecticidal effects of the studied EOs in this study could be due to the thujone identified by GC-MS in EOA.

For better understating this insecticidal effect of EOs, the study conducted by Senthil-Nathan [61] revealed that botanical chemicals affect the metabolism and growth of insects through physiological processes and enzymatic activities. In this way, understanding the biochemical effects of pesticides on insects can certainly provide safe pest control strategies [62]. In this sense, and according to França et al. [63], botanical insecticides can act on insects as acetylcholinesterase (AChE) inhibitors. So that the inhibition of AChE by phytochemicals, especially monoterpenoids, causes blockage of the neurotransmitter acetylcholine at the synaptic cleft [64], which is the case for the EOs tested in our study, whose essences are rich in compounds with a strong insecticidal effect against C. maculatus. Indeed, the pharmacological effect occurred at the level of chloride channels, octopamine receptors, tyramine receptors, acetylcholine esterase, nicotinic acetylcholine receptors (nAChR), and sodium channels in C. maculatus treated with EOs may be due to the individual activity of single compound or due to synergistic relationship of several chemical compounds because EOs contain a complex mixture of constituents that can interact with many target molecules [22]. EO compounds can also act with a variety of other targets including g-aminobutyric acid (GABA) gated.

A study was carried out by François Renoz et al. [65] on the mode of action of the $\mathrm{EO}$ of $M$. arvensis tested by contact on adult Sitophilus granarius, leading to rapid paralysis and alteration of walking behavior. This study revealed that the EOs of Mentha arvensis induced dramatic physiological changes in the exposed insects. In this case, the majority of differentially expressed proteins (DEPs) related to the muscle and nervous system were dysregulated along with serious problems affecting cellular respiration, protein synthesis, and detoxification process.
These results suggest that EOs are capable of affecting a variety of biological processes.

The obtained findings showed that a significant reduction in fecundity and emergence rate was recorded. This is could be explained by ovicidal and larvicidal activities of the tested EOs that potentially creep into eggs, which in turn result in the blockage of embyogenesis $[65,66]$. The ovicidal activity of the EOs would be due to the direct effects of their compounds leading to the inhibition of the metabolic activity of the eggs. This is the case of piperitone isolated from the EOs of Cymbopogon schoenanthus L. on the eggs of Callosobruchus maculatus. Moreover, $ß$-arasone identified in the EOs of Acorus calamus L. showed toxicity on the eggs of Callosobruchus chinensis, Sitophilus oryzae L., and Sitophilus granarius L. [67]. In addition, according to Schmidt et al. [67], EOs have a sterilizing effect on eggs. Previous works carried out on Acanthoscelides obtectus belonging to the family Bruchidae, showed high sensitivity of eggs to the vapors of Eos from Lavandula hybrid L., Rosmarinus officinalis L., and Eucalyptus globules L. [68].

The percentage of repulsion effect evaluated by the method of McDonald et al. [37] showed that the EOA, EOD, and EOM were repulsive towards C. maculatus with a respective rate of $60 \%$. In this context, Papachristos and Stamopoulos [69] showed that EOs of 13 aromatic plants, five of them Monardella viridis L., Eucalyptus globulus L., Melaleuca microphylla L., Rosmarinus officinalis L., and Lysimachia hybrid L. showed significant repulsive effects against Theileria orientalis L. and Clonorchis sinensis L. Furthermore, these authors reported that the most toxic EO exhibited simultaneously repulsive and reproductive inhibitory effects on bean bruchid, so that our results were in agreement with this literature.

Further works aim to evaluate potential toxicities of the studied EOs on nontarget organisms, and humans will be more appreciated prior to developing insecticide-based essential oils.

\section{Conclusion}

This study concluded that the essential oils from Artemisia herba alba Asso. and Maticaria Recutita L. and Dittrichia Viscosa L. well controlled the development of Callosobruchus maculatus with more attention can be paid to Artemisia herba alba Asso. essential oil rich in alpha thujone, betathujone, and chrysanthenone. The obtained results in this study showed that the use of essential oils as a biological pesticide could be incorporated in the management program for the control of chickpea pests as a safe alternative form.

\section{Data Availability}

Data used to support the findings are included within the article.

\section{Conflicts of Interest}

The authors declare that they have no conflicts of interest. 


\section{Authors' Contributions}

A. A., M. B., H. H., R. S., and A. M. S. contributed to original draft preparation and review and editing. W. S., H. Z. R., L. O., and E. A. Y. carried out formal analysis and review and editing. E. N. and F. M. performed conceptualization and supervision.

\section{Acknowledgments}

This research was funded by the Researchers Supporting Project (number RSP-2021/390), King Saud University, Riyadh, Saudi Arabia, and the authors extend their appreciation for the support.

\section{References}

[1] M. Jallow, D. Awadh, M. Albaho, V. Devi, and N. Ahmad, "Monitoring of pesticide residues in commonly used fruits and vegetables in Kuwait," International Journal of Environmental Research and Public Health, vol. 14, no. 8, p. 833, 2017.

[2] N. Lumjuan, S. Rajatileka, D. Changsom et al., "The role of the Aedes aegypti epsilon glutathione transferases in conferring resistance to DDT and pyrethroid insecticides," Insect Biochemistry and Molecular Biology, vol. 41, no. 3, pp. 203-209, 2011.

[3] S. Mostafalou and M. Abdollahi, "Pesticides: an update of human exposure and toxicity," Archives of Toxicology, vol. 91, no. 2, pp. 549-599, 2017.

[4] K. Yu, G. Li, W. Feng et al., "Chlorpyrifos is estrogenic and alters embryonic hatching, cell proliferation and apoptosis in zebrafish," Chemico-Biological Interactions, vol. 239, pp. 2633, 2015.

[5] Y. Zhang, M. Lu, P. Zhou, C. Wang, Q. Zhang, and M. Zhao, "Multilevel evaluations of potential liver injury of bifenthrin," Pesticide Biochemistry and Physiology, vol. 122, pp. 29-37, 2015.

[6] N. G. Kavallieratos, M. C. Boukouvala, N. Ntalli et al., "Effectiveness of eight essential oils against two key storedproduct beetles, prostephanus truncatus (horn) and trogoderma granarium everts," Food and Chemical Toxicology, vol. 139, Article ID 111255, 2020.

[7] M. S. AlSalhi, K. Elumalai, S. Devanesan, M. Govindarajan, K. Krishnappa, and F. Maggi, "The aromatic ginger Kaempferia galanga L. (Zingiberaceae) essential oil and its main compounds are effective larvicidal agents against Aedes vittatus and Anopheles maculatus without toxicity on the nontarget aquatic fauna," Industrial Crops and Products, vol. 158, Article ID 113012, 2020.

[8] Z. Banihashemi and C. Abivardi, "Evaluation of fungicidal and fungistatic activity of plant essential oils towards plant pathogenic and saprophytic fungi," Phytopathologia Mediterranea, vol. 50, pp. 245-256, 2011.

[9] M. Atif, S. Ilavenil, S. Devanesan et al., "Essential oils of two medicinal plants and protective properties of jack fruits against the spoilage bacteria and fungi," Industrial Crops and Products, vol. 147, Article ID 112239, 2020.

[10] L. Dargahi, K. Razavi-Azarkhiavi, M. Ramezani, M. R. Abaee, and J. Behravan, "Insecticidal activity of the essential oil of thymus transcaspicus against Anopheles stephensi," Asian Pacific Journal of Tropical Biomedicine, vol. 4, pp. S589-S591, 2014.
[11] G. Benelli, R. Pavela, E. Drenaggi, and F. Maggi, "Insecticidal efficacy of the essential oil of jambú (Acmella oleracea (L.) R. K. Jansen) cultivated in central Italy against filariasis mosquito vectors, houseflies and moth pests," Journal of Ethnopharmacology, vol. 229, pp. 272-279, 2019.

[12] R. Pavela, F. Maggi, R. Petrelli et al., "Outstanding insecticidal activity and sublethal effects of Carlina acaulis root essential oil on the housefly, Musca domestica, with insights on its toxicity on human cells," Food and Chemical Toxicology, vol. 136, Article ID 111037, 2020.

[13] A. Pandey, P. Chattopadhyay, S. Banerjee, K. Pakshirajan, and L. Singh, "Antitermitic activity of plant essential oils and their major constituents against termite odontotermes assamensis holmgren (isoptera: termitidae) of north east India," International Biodeterioration \& Biodegradation, vol. 75, pp. 63-67, 2012.

[14] J. K. A. Lima, E. L. D. Albuquerque, A. C. C. Santos et al., "Biotoxicity of some plant essential oils against the termite nasutitermes corniger (isoptera: termitidae)," Industrial Crops and Products, vol. 47, pp. 246-251, 2013.

[15] C. Nagawa, S. Böhmdorfer, and T. Rosenau, "Chemical composition and anti-termitic activity of essential oil from canarium schweinfurthii engl," Industrial Crops and Products, vol. 71, pp. 75-79, 2015.

[16] A. A. Santos, B. M. S. de Oliveira, C. R. Melo et al., "Sub-lethal effects of essential oil of Lippia sidoides on drywood termite Cryptotermes brevis (blattodea: termitoidea)," Ecotoxicology and Environmental Safety, vol. 145, pp. 436-441, 2017.

[17] S. Janaki, N. Zandi-Sohani, L. Ramezani, and A. Szumny, "Chemical composition and insecticidal efficacy of Cyperus rotundus essential oil against three stored product pests," International Biodeterioration \& Biodegradation, vol. 133, pp. 93-98, 2018.

[18] I. A. T. d. A. Ribeiro, R. da Silva, A. G. da Silva et al., "Chemical characterization and insecticidal effect against Sitophilus zeamais (maize weevil) of essential oil from Croton rudolphianus leaves," Crop Protection, vol. 129, Article ID 105043, 2020.

[19] K. Magierowicz, E. Górska-Drabik, and C. Sempruch, "The effect of Tanacetum vulgare essential oil and its main components on some ecological and physiological parameters of Acrobasis advenella (zinck.) (Lepidoptera: Pyralidae)," Pesticide Biochemistry and Physiology, vol. 162, pp. 105-112, 2020.

[20] K. Magierowicz, E. Górska-Drabik, and C. Sempruch, "The insecticidal activity of Satureja hortensis essential oil and its active ingredient-carvacrol against Acrobasis advenella (zinck.) (Lepidoptera, Pyralidae)," Pesticide Biochemistry and Physiology, vol. 153, pp. 122-128, 2019.

[21] W.-S. Choi, B.-S. Park, Y.-H. Lee, D. Y. Jang, H. Y. Yoon, and S.-E. Lee, "Fumigant toxicities of essential oils and monoterpenes against lycoriella Mali adults," Crop Protection, vol. 25 , no. 4 , pp. $398-401,2006$.

[22] F. Tong and J. R. Coats, "Effects of monoterpenoid insecticides on $[3 \mathrm{H}]-\mathrm{TBOB}$ binding in house fly GABA receptor and 36Cl-uptake in American cockroach ventral nerve cord," Pesticide Biochemistry and Physiology, vol. 98, no. 3, pp. 317-324, 2010.

[23] J.-H. Tak, E. Jovel, and M. B. Isman, "Comparative and synergistic activity of Rosmarinus officinalis L. essential oil constituents against the larvae and an ovarian cell line of the cabbage looper, Trichoplusia ni (Lepidoptera: noctuidae)," Pest Management Science, vol. 72, no. 3, pp. 474-480, 2016.

[24] A. S. Hashem, M. M. Ramadan, A. A. A. Abdel-Hady, S. Sut, F. Maggi, and S. Dall'Acqua, "Pimpinella anisum essential oil 
nano emulsion toxicity against Tribolium castaneum? Shedding light on its interactions with aspartate aminotransferase and alanine aminotransferase by molecular docking," Molecules, vol. 25, no. 20, p. 4841, 2020.

[25] R. Pavela and G. Benelli, "Ethnobotanical knowledge on botanical repellents employed in the African region against mosquito vectors - a review," Experimental Parasitology, vol. 167, pp. 103-108, 2016.

[26] L. A. Ogunkanmi, O. T. Ogundipe, O. D. Amusa, B. Bolarinwa, and O. O. Akindele, "Comparative evaluation of cold and container storage preservation efficiencies on cowpea grains against Callosobruchus maculatus Fab," 2018.

[27] A. Allali, S. Rezouki, S. Mostafa, M. Dalale, E. Noureddine, and F. Mohamed, "GC-MS analysis of essential oil composition and insecticidal activity of syzygium aromaticum against Callosobruchus maculatus of chickpea," Tropical Journal of Natural Product Research, vol. 5, no. 5, pp. 844-849, 2021.

[28] F. Bidar, J. Razmjou, A. Golizadeh, S. A. Asghar Fathi, A. Ebadollahi, and B. Naseri, "Effect of different legume seeds on life table parameters of cowpea weevil, Callosobruchus maculatus (F.) (Coleoptera: chrysomelidae)," Journal of Stored Products Research, vol. 90, Article ID 101755, 2021.

[29] O. O. Uyi and O. G. Igbinoba, "Repellence and toxicological activity of the root powder of an invasive alien plant, chromolaena odorata (L.)(Asteraceae) against Callosobruchus maculatus (Fab.)(Coleoptera: chrysomelidae)," Animal Research International, vol. 13, pp. 2510-2517, 2016.

[30] S. Haouel Hamdi, S. Abidi, D. Sfayhi et al., "Nutritional alterations and damages to stored chickpea in relation with the pest status of Callosobruchus maculatus (chrysomelidae)," Journal of Asia Pacific Entomology, vol. 20, no. 4, pp. 10671076, 2017.

[31] A. Allali, S. Rezouki, B. Louasté et al., "Study of the nutritional quality and germination capacity of cicer arietinum infested by Callosobruchus maculatus (Fab.)," Plant Cell Biotechnology and Molecular Biology, vol. 21, pp. 44-56, 2020.

[32] O. M. Obembe, D. O. Ojo, and K. D. Ileke, "Efficacy of Kigelia africana (lam.) benth. Plant extracts on cowpea seed beetle, Callosobruchus maculatus fabricius [Coleoptera: chrysomelidae] affecting stored cowpea seeds, vigina unguiculata," Heliyon, vol. 6, Article ID e05215, 2020.

[33] J. Hardie, R. Isaacs, J. A. Pickett, L. J. Wadhams, and C. M. Woodcock, "Methyl salicylate and (-)-(1R,5S)-myrtenal are plant-derived repellents for black bean aphid, Aphis fabae Scop. (Homoptera: aphididae)," Journal of Chemical Ecology, vol. 20, no. 11, pp. 2847-2855, 1994.

[34] J. F. Clevenger, "Apparatus for the determination of volatile oil *," Journal of the American Pharmaceutical Association 1912, vol. 17, no. 4, pp. 345-349, 1928.

[35] K. d. A. K. Dutra, D. M. d. A. F. Navarro, D. R. e. S. Barbosa, and J. P. O. Santos, "Control of Callosobruchus maculatus (FABR.) (Coleoptera: chrysomelidae: Bruchinae) in Vigna unguiculata (L.) WALP. with essential oils from four Citrus spp. plants," Journal of Stored Products Research, vol. 68, pp. 25-32, 2016.

[36] A. Aimad, R. Sanae, F. Anas et al., "Chemical characterization and antioxidant, antimicrobial, and insecticidal properties of essential oil from Mentha pulegium L," Evidence-based Complementary and Alternative Medicine, vol. 2021, Article ID 1108133, 12 pages, 2021.

[37] L. L. McDonald, R. H. Guy, and R. D. Speirs, Preliminary Evaluation of New Candidate Materials as Toxicants,
Repellents, and Attractants Against Stored-Product Insects, US Agricultural Research Service, Maryland, MD, USA, 1970.

[38] N. Zandi-Sohani, M. Hojjati, and Á. A. Carbonell-Barrachina, "Insecticidal and repellent activities of the essential oil of Callistemon citrinus (myrtaceae) against Callosobruchus maculatus (F.) (Coleoptera: Bruchidae)," Neotropical Entomology, vol. 42, no. 1, pp. 89-94, 2013.

[39] S. Rezouki, A. Allali, L. Bouchra, N. Eloutassi, and M. Fadli, "The impact of the harvesting period and drying conditions on the essential oil yield of Rosmarinus officinalis, Thymus satureioides and Origanum compactum from the TazaTaounate region," Asian Journal of Agriculture and Biology, vol. 2021, no. 3, Article ID 202004251, 2021.

[40] D. J. Finney, Probit Analysis, Cambridge University, London, UK, 3rd edition, 1971.

[41] S. Rezouki, A. Allali, N. ELoutassi, and M. Fadli, "Biotechnological valorization of aromatic plants in morocco: impact of extraction methods on the yield and chemical composition of origanum compactum benth. of taounate (Northern Morocco)," Plant Cell Biotechnology and Molecular Biology, 21(61®62), pp. 56-62, 2020.

[42] E. Mohammed, J. Fliou, O. Riffi, A. Amechrouq, and Y. Ghouati, "Comparative study of the chemical composition of the essential oil of Origanum compactum from the seven regions of Morocco and their antimicrobial activity," Journal of Microbiology, Biotechnology and Food Sciences, vol. 10, pp. 42-48, 2020.

[43] A. Zeroual, E. H. Sakar, N. Eloutassi, F. Mahjoubi, M. Chaouch, and A. Chaqroune, "Phytochemical profiling of essential oils isolated using hydrodistillation and microwave methods and characterization of some nutrients in origanum compactum benth from central-northern Morocco," Biointerface Research in Applied Chemistry, vol. 11, pp. 93589371, 2021.

[44] M. Abdelli, H. Moghrani, A. Aboun, and R. Maachi, "Algerian Mentha pulegium L. Leaves essential oil: chemical composition, antimicrobial, insecticidal and antioxidant activities," Industrial Crops and Products, vol. 94, pp. 197-205, 2016.

[45] K. Khelfane-Goucem, N. Lardjane, and F. Medjdoub-Bensaad, "Fumigant and repellent activity of rutaceae and lamiaceae essential oils against Acanthoscelides obtectus say," African Journal of Agricultural Research, vol. 11, pp. 14991503, 2016.

[46] M. Pourya, A. Sadeghi, H. Ghobari, C. N. T. Taning, and G. Smagghe, "Bioactivity of Pistacia atlantica desf. Subsp. kurdica (Zohary) Rech. F. and Pistacia khinjuk stocks essential oils against Callosobruchus maculatus (F, 1775) (Coloeptera: Bruchidae) under laboratory conditions," Journal of Stored Products Research, vol. 77, pp. 96-105, 2018.

[47] M. Mahmoudvand, H. Abbasipour, M. Basij, M. H. Hosseinpour, F. Rastegar, and M. B. Nasiri, "Fumigant toxicity of some essential oils on adults of some storedproduct pests," Chilean Journal of Agricultural Research, vol. 71, no. 1, pp. 83-89, 2011.

[48] L. Aboa, B. P. Seri-Kouassi, and H. Koua, "Insecticidal activity of essential oils from three aromatic plants on Callosobruchus maculatus F. in cotê D'evoire," European Journal of Scientific Research, vol. 39, pp. 243-250, 2010.

[49] B. Z. Sahaf and S. Moharramipour, "Fumigant toxicity of Carum copticum and Vitex pseudo-negundo essential oils against eggs, larvae and adults of Callosobruchus maculatus," Journal of Pest Science, vol. 81, no. 4, pp. 213-220, 2008.

[50] C. A. Filomeno, L. C. Almeida Barbosa, R. R. Teixeira et al., "Chemical diversity of essential oils of myrtaceae species and 
their insecticidal activity against Rhyzopertha dominica," Crop Protection, vol. 137, Article ID 105309, 2020.

[51] A. M. E. Abd El-Salam, S. Abd elwahed Salem, and R. S. Abdel-Rahman, "Fumigant and toxic activity of some aromatic oils for protecting dry dates from Oryzaephilus surinamensis (L.)(Coleoptera: silvanidae) in stores," Bulletin of the National Research Centre, vol. 43, pp. 1-6, 2019.

[52] J.-q. Cao, X. Pang, S.-s. Guo et al., "Pinene-rich essential oils from Haplophyllum dauricum (L.) G. Don display anti-insect activity on two stored-product insects," International Biodeterioration \& Biodegradation, vol. 140, pp. 1-8, 2019.

[53] L. F. Douiri, A. Boughdad, M. H. Alaoui, and M. Moumni, "Biological activity of Rosmarinus officinalis essential oils against Callosobruchus maculatus,(Coleoptera, bruchinae)," Journal of Biology, Agriculture and Healthcare, vol. 4, pp. 5-14, 2014.

[54] C. Regnault-Roger, C. Vincent, and J. T. Arnason, "Essential oils in insect control: low-risk products in a high-stakes world," Annual Review of Entomology, vol. 57, no. 1, pp. 405-424, 2012.

[55] A. K. Tripathi, P. Veena, K. K. Aggarwal, and K. Sushil, "Effect of volatile oil constituents of Mentha species against the stored grain pests, Callosobruchus maculatus and Tribolium castaneum," Journal of Medicinal and Aromatic Plant Sciences, vol. 22, pp. 549-556, 2000.

[56] F. Titouhi, M. Amri, C. Messaoud et al., "Protective effects of three Artemisia essential oils against Callosobruchus maculatus and Bruchus rufimanus (Coleoptera: chrysomelidae) and the extended side-effects on their natural enemies," Journal of Stored Products Research, vol. 72, pp. 11-20, 2017.

[57] A. I. Hussain, "Characterization and biological activities of essential oils of some species of lamiaceae," M.Sc thesis, University of Agriculture, Faisalabad, Pakistan, 2009.

[58] S. A. M. Abdelgaleil, M. I. E. Mohamed, M. E. I. Badawy, and S. A. A. El-arami, "Fumigant and contact toxicities of monoterpenes to Sitophilus oryzae (L.) and Tribolium castaneum (herbst) and their inhibitory effects on acetylcholinesterase activity," Journal of Chemical Ecology, vol. 35, no. 5, pp. 518-525, 2009.

[59] K. K. Aggarwal, A. K. Tripathi, A. Ahmad, V. Prajapati, N. Verma, and S. Kumar, "Toxicity of L-menthol and its derivatives against four storage insects," International Journal of Tropical Insect Science, vol. 21, no. 03, pp. 229-235, 2001.

[60] O. Bachrouch, N. Ferjani, S. Haouel, and J. M. B. Jemâa, "Major compounds and insecticidal activities of two Tunisian Artemisia essential oils toward two major coleopteran pests," Industrial Crops and Products, vol. 65, pp. 127-133, 2015.

[61] S. Senthil-Nathan, "A review of biopesticides and their mode of action against insect pests," Environmental Sustainability, Springer, Berlin, Germany, pp. 49-63, 2015.

[62] T. Hu, J. Xu, Y. Ye et al., "Visual detection of mixed organophosphorous pesticide using QD-AChE aerogel based microfluidic arrays sensor," Biosensors and Bioelectronics, vol. 136, pp. 112-117, 2019.

[63] L. P. França, A. C. F. Amaral, A. d. S. Ramos et al., "Piper capitarianum essential oil: a promising insecticidal agent for the management of Aedes aegypti and Aedes albopictus," Environmental Science and Pollution Research, vol. 28, no. 8, pp. 9760-9776, 2021.

[64] M. D. López and M. J. Pascual-Villalobos, "Mode of inhibition of acetylcholinesterase by monoterpenoids and implications for pest control," Industrial Crops and Products, vol. 31, no. 2, pp. 284-288, 2010.
[65] J. A. Wightman and B. J. Southgate, "Egg morphology, host, and probable regions of origin of the bruchids (Coleoptera: Bruchidae) that infest stored pulses-an identification aid," New Zealand Journal of Experimental Agriculture, vol. 10, no. 1, pp. 95-99, 1982.

[66] P. F. Credland, "The structure of bruchid eggs may explain the ovicidal effect of oils," Journal of Stored Products Research, vol. 28, no. 1, pp. 1-9, 1992.

[67] G. H. Schmidt, E. M. Risha, and A. K. M. El-Nahal, "Reduction of progeny of some stored-product coleoptera by vapours of Acorus Calamus oil," Journal of Stored Products Research, vol. 27, no. 2, pp. 121-127, 1991.

[68] D. P. Papachristos and D. C. Stamopoulos, "Fumigant toxicity of three essential oils on the eggs of Acanthoscelides obtectus (Say) (Coleoptera: Bruchidae)," Journal of Stored Products Research, vol. 40, no. 5, pp. 517-525, 2004.

[69] D. P. Papachristos and D. C. Stamopoulos, "Toxicity of vapours of three essential oils to the immature stages of Acanthoscelides obtectus (Say) (Coleoptera: Bruchidae)," Journal of Stored Products Research, vol. 38, no. 4, pp. 365373, 2002. 